\title{
WORK-LIFE BALANCE: CHALLENGES OF GENDER EQUALITY IN THE LABOR MARKET IN THE REPUBLIC OF NORTH MACEDONIA VS EUROPEAN UNION
}

\author{
Biljana Todorova, PhD, Associate Professor \\ University „Goce Delcev” - Shtip, Faculty of Law \\ „Krste Misirkov“No.10-A P.O. Box 201, Shtip 2000, \\ Republic of North Macedonia \\ biljana.todorova@ugd.edu.mk
}

\author{
Makedonka Radulovikj, PhD, Associate Professor \\ University of "Ss. Cyril and Methodius", \\ Institute for Family Studies, Faculty of Philosophy \\ Skopje 1000, Republic of North Macedonia \\ radulovik@fzf.ukim.edu.mk
}

\begin{abstract}
Work-life balance is the term used to describe practices in achieving a balance between the demands of employees' family (life) and work lifes. Employers today strive to augment job satisfaction in the workforce for it is conducive to lower employee turnover, higher engagement, and greater productivity. Besides the feminists, who discuss women's inequality with men in the family and the separation of the family responsibilities, the term "work-life balance", addressing the aspects of achieving this balance, starts to be more commonly used in employment policies. The dramatic increase in female labor force participation in the labor market, as a result of the collapse of the so-called "male breadwinner" model, often results in a "double burden" for paid women. On the other hand, there is a tendency among employers to increase workforce satisfaction because it has been shown to reduce employee turnover and produce higher engagement and increased productivity.

Policies for the harmonization of work and private life are covered by social legislation and labor legislation. The International Labor Organization defines the work-life balance as one of the greatest challenges of our time.
\end{abstract}


One of the aims of the European Social Rights Pillar is the Work-life balance Initiative which addresses the challenges of work-family balance faced by working parents and carers. Therefore, a directive on the balance between the working and professional life of parents and carers have recently been adopted in the European Union. It sets several new or higher standards for absent parents, paternity and guardianship and enforces a greater use of flexible employment contracts. Its aim is to increase the inclusion of women in the labor market and to promote greater use of parental leave by male workers.

Motivated by this, a comparative analysis and critical overview is made between the policies existing in the member states of the European Union and the Republic of North Macedonia which are directly related to the promotion of family-work balance. The purpose of this paper is to see how the Macedonian labor and the legal system is prepared to respond to the challenge posed by this Directive and to provide suggestions and guidance that would improve the situation in the domestic labor market.

Keywords: work-life balance, work, employment, family policies, flexibility, labor law legislation.

\section{INTRODUCTION}

The reality of today's workforce is that workers hold several different roles in life. People increasingly juggle a range of activities, interests and relationships outside work while still striving to meet growing demands in the workplace for quality goods and services around the clock. How to combine work with life is a fundamental issue for many people. An issue that policymakers, social partners, businesses and individuals are seeking to resolve. Simultaneously, new challenges and solutions are transforming the interface between work and life: an aging population, technological change, higher employment rates and fewer weekly working hours.

Work-life balance is the lack of opposition between work and other life roles. It is the state of equilibrium in which demands of personal life, professional life and family life are equal.

Although the literature is replete with discussion on work-life balance, the definitions of work-life balance are many and varied. Almost every article on work-life balance has a different definition of what work-life balance actually is. Work-life balance is defined as "achieving satisfying experiences in all life domains to a level consistent with the salience of each role for the individual.... (that) introduces the possibility of a hierarchy of roles; however... it does not demand that a hierarchy is neither necessary nor desirable for balance". ${ }^{1}$ Greenblatt is describing work-life balance as acceptable levels of conflict between work and nonwork demands. ${ }^{2}$

\footnotetext{
1 Reiter, N., Work Life Balance: What DO You Mean? The Ethical Ideology Underpinning Appropriate Application, The Journal of Applied Behavioral Science, NTL Institute, 2007, p. 277

2 Greenblatt, E., Workllife balance: Wisdom or whining, Organizational Dynamics, 2002, p. 177
} 
Enabling a better work-life balance for workers across the life course has been a European Union policy goal for many years as it is central to ensuring that work is sustainable for all. It is also an important factor in determining the participation of women and older workers in the labor market. The work-life balance consists of, but it is not limited to, flexible work arrangements that allow employees to carry out other life programs and practices. The term „work-life balance" is recent in origin, as it was first used in the United Kingdom and the United States of America in the late 1970s and 1980s, respectively. Work-life balance is a term commonly used to describe the balance that a working individual needs between time allocated for work and other aspects of life. Areas of life other than work-life can include personal interests, family and social or leisure activities. Technological advances have made it possible for work tasks to be accomplished faster due to the use of smartphones, email, video chat and other technological software. These technological advances facilitate individuals to work without having a typical 9 to 5 o'clock workday.

The International Labor Organization defines work-family balance as one of the greatest challenges of our time. Reconciling work and family is an essential aspect of promoting equality in the field of labor and reducing poverty. The realization of equal opportunities for men and women ensures equal participation of women and men in all areas of the public and private sectors, equal status and treatment in the exercise of their rights and equal benefits from the results achieved. ${ }^{3}$

The term "harmonization of private and professional life" or "work-life balance" is becoming an increasingly pressing issue in European Union policies. Following the withdrawal of the Maternity Leave Directive, the Commission decided to take a broader approach in addressing women's underrepresentation in the labor market. One of the deliverables of the European Pillar of Social Rights ${ }^{4}$ is the Worklife Balance Initiative which addresses the work-life balance challenges faced by working parents and carers. This initiative takes into account the developments in society over the past decade to enable parents and people with caring responsibilities to better balance their work and family lives and to encourage a better sharing of caring responsibilities between women and men. It was based on the results of

3 Relevant ILO Conventions and Recommendation: Convention Maternity Protection Convention, 2000 (No. 183); Part-Time Work Convention, 1994 (No. 175). Workers with Family Responsibilities Convention, 1981 (No. 156); Workers with Family Responsibilities Recommendation, 1981 (R165). Part-Time Work Recommendation, 1994 (R182); Reduction of Hours of Work Recommendation, 1962 (R116)

4 European Pillar of Social Rights, booklet, adopted by The European Parliament, the Council and the Commission, 2017. The Pillar sets out 20 key principles and rights to support fair and well-functioning labor markets, structured around three chapters: equal opportunities and access to the labor market, fair working conditions, social protection, and inclusion 
the public consultation and two-stage social partner consultation, and the analysis of the accompanying impact assessment. On 17 November 2017, the European Parliament, the Council, and the European Commission formally proclaimed the European Pillar of Social Rights, which included an initiative to support worklife balance. Subsequently, in June 2019, the Council adopted a new Directive on work-life balance for parents and carers. The Directive aims to increase women's participation in the labor market and outlines several new or improved minimum standards for parental, paternity and carers leave, as well as flexible working arrangements, aiming to also increase men's take-up of these. ${ }^{5}$

Main elements of the directive:

- paternity leave - fathers or second parents will be able to take at least 10 working days of leave around the time of the birth of a child, paid at a level equal to that currently set at EU level for maternity leave (in line with article 11 of Council Directive 92/85/EEC). The right to paternity leave will not be subject to a prior service requirement. However, the payment of paternity leave can be subject to a six-month prior service requirement. Member states with more generous parental leave systems will be able to keep their current national arrangements.

- parental leave - an individual right to 4 months of parental leave from which 2 months are non-transferable between the parents and are paid. The level of payment and the age limit of the child will be set by member states.

- carer's leave - a new concept at the EU level for workers caring for relatives in need of care or support due to serious medical reasons. Carers will be able to take 5 working days per year. Member states may use a different reference period, allocate leave on a case-by-case basis and may introduce additional conditions for the exercise of this right.

- flexible working arrangements - the right for parents to request these arrangements has been extended to include working carers.

In addition to feminists arguing for women's inequality with men in the family and separation of family responsibilities, the term "work-life balance" has also been widely used in employment policies.

Due to changes in employment forms and job requirements and changes in family structure, reconciliation of work and family life in recent years in the European Union has become very important. In particular, the evolution of society and the changing character of jobs require organizational change and greater flexibility, while taking into account the needs of both workers and employers. In response to new needs, some

Directive (EU) 2019/1158 of the European Parliament and of the Council of 20 June 2019 on worklife balance for parents and carers and repealing Council Directive 2010/18/EU 
countries have implemented new family policies with an emphasis on increasing parental employment rates. They are designed to support women in overcoming obstacles to full participation in the labor market compared to their male colleagues.

In addition to promoting family-work balance, the goal of these employment policies is to make full use of the labor force of both men and women. However, given the overall employment rate of women, they still fall behind men. ${ }^{6}$ For women and men to have access to the labor market on the same basis, there is a need for institutional policies to enable the reconciliation of private and professional life.

The Government of The Republic of North Macedonia "inherited" the ratified Convention No. 156 on Workers with Family Responsibilities from the previous Socialist Federal Republic of Yugoslavia. When the political system changed in 1991, so did the legal framework to allow for major developments such as capital transformation. Today the entire policy framework on labor relations, family protection, child protection and social protection is new. For this reason it is interesting to examine whether the specific needs of workers with family responsibilities are well-recognized in the new legislation, what successive governments since 1991 have done to promote the principles and values of Convention No.156 and the impact on workplaces and workers, and the measures to be taken to implement the new Directive on work-life balance. ${ }^{7}$

\section{LEGAL AND POLICY MEASURES IN THE EUROPEAN UNION}

To address the challenges that working parents carers face in reconciling work and family responsibilities, the European Commission proposed the 'Work-life balance' Initiative in April 2017. This initiative is a key deliverable of the European Pillar of Social Rights. The Directive on work-life balance sets some new or higher standards for parental, paternity and carers leave and the right to request flexible working arrangements. It takes account of the needs of small and medium-sized

The authors found that while there is diversity across countries and life stages relative to family composition, living as a couple with a child is the most prominent structure for 35-49 year olds. The household workload consists primarily of care responsibilities, with childcare occupying more time than caring for relatives. Additionally, the study found that for women, time spent working in the home does not differ significantly across countries. The gender gap exists relative to perceptions of gender roles and inequality in time spent doing household tasks. Additionally, the study found that men perceived that they do fewer household chores whereas women felt that they do more than their fair share of chores. Kotowska, E.I. et al., Second European Quality of Life Survey: Family life and work, Office for Official Publications of the European Communities, Luxembourg, 2010, pp.1-96

7 Cruz, A., Good practices and challenges on the Maternity Protection Convention, 2000 (No. 183) and the Workers with Family Responsibilities Convention, 1981 (No. 156): A comparative study, International Labour Organization, 2012, p. 109 
companies and makes sure that they are not disproportionately affected. The new Directive is complemented with policy and funding measures, supporting EU countries in enforcing existing dismissal protection legislation, developing formal care services and addressing economic disincentives for second earners to work. ${ }^{8}$

The adopted Directive aims at modernizing the existing European Union legal framework in the area of family-related leaves and flexible working arrangements. The Directive on work-life balance for parents and carers includes:

- Introduction of paternity leave. Fathers/equivalent second parents will be able to take at least 10 working days of paternity leave around the time of the birth of the child, compensated at least at the level of sick pay.

- Strengthening of the existing right to 4 months of parental leave by making 2 out of the 4 months non-transferable from a parent to another, and compensated at a level to be set by the Member States. Parents will also have the right to request to take the leave in a flexible way (e.g. part-time or in a piecemeal approach).

- Introduction of carer's leave for workers providing personal care or support to a relative or person living in the same household. Working carers will be able to take 5 days per year.

- Extension of the existing right to request flexible working arrangements (reduced working hours, flexible working hours and flexibility in place of work) to all working parents of children up to at least 8 years old and all carers.

To complement the adopted legislative, a set of non-legislative measures are taken to support the Member States in achieving these common goals. These include:

- Ensuring protection against discrimination and dismissal for parents (including pregnant women and workers coming back from leave) and carers;

- Encouraging a gender-balanced use of family-related leaves and flexible working arrangements;

- Making better use of European funds to improve the provision of formal care services (childcare, out-of-school care and long-term care);

- Removing economic disincentives for second earners which prevent women from accessing the labor market or working full-time.

This will benefit individuals, companies and the wider society. Parents and carers will profit from a better work-life balance. Moreover, the foreseen increase in women's employment, their higher earnings and career progression will positively

$8 \quad[$ https://ec.europa.eu/social/main.jsp?langId=en\&catId=1311\&furtherNews=yes\&newsId=9285], accessed 15 . January 2020 
impact their and their families' economic prosperity, social inclusion and health. Companies will benefit from a wider talent pool and a more motivated and productive labor force, as well as from less absenteeism. The rise in women's employment will also contribute to addressing the challenge of demographic aging and ensuring Member States' financial stability.

The new Directive will help working parents and carers by not obliging them to choose between their family lives and their professional careers. It sets new or higher minimum standards to create more convergence between the EU Member States by preserving and extending existing rights. As mentioned, the new Directive will improve working parents and carers conditions and lead to women's higher employment rate, earnings and better career progression. Gender pay and pension gaps, as well as women's exposure to poverty, will be reduced. Fathers will have more opportunities and incentives to participate in family life. Caregivers looking after an elderly, ill or disabled relative will be able to take time off from work. More women in the labor market will increase the available talent pool. Skills shortages will be addressed. Businesses will better attract and retain workers. Workers will be less absent from work and more motivated, which will improve companies' productivity. In Member States public finances will be more sustainable by reducing unemployment and increasing tax incomes. Increasing labor supply will boost competitiveness. Demographic challenges will be addressed by making full use of our human capital. ${ }^{10}$

\section{POLICIES FOR WORK/LIFE BALANCE IN THE REPUBLIC OF NORTH MACEDONIA}

At the national level, according to the Law on Labor Relation, the full-time hours of work should not exceed 40 hours per week. The workweek lasts, by rule, five workdays. The law, i.e., a collective agreement may stipulate a working time to be less than 40 hours but not less than 36 hours of work per week. This kind of working time shall be deemed full-time hours. If the full-time working hours are not defined by law or collective agreement, 40 hours of work per week shall be deemed full-time hours. ${ }^{11}$ The official working time is from 8 am until 4 pm from Monday to Friday. The employee shall be entitled to a weekly rest period of at least 24 uninterrupted hours, plus the 12-hour daily rest period referred to in article

\footnotetext{
9 [https://ec.europa.eu/social/main.jsp?catId=1311\&langId=en], accessed 20. January 2020

10 European Commission, A new start to support work-life balance for parents and carers, 2019, p. 2

11 Law on Labour Relations ("Official Gazette of the Republic of Macedonia" no. 62/05, 106/08, 161/08, $114 / 09,130 / 09,50 / 10,52 / 10,124 / 10,47 / 11,11 / 12,39 / 12,13 / 13,25 / 13,170 / 13,187 / 13,113 / 14$, 20/15, 33/15, 72/15, 129/15 and 27/16). Article 116 (1), (2), (3), (5)
} 
133 of the present law. By rule, Sunday or other day in the week shall be the day of weekly rest. ${ }^{12}$ Usually the weekend is free but many private companies also work on Saturday. Employees are entitled to annual leave of between 20 and 26 working days per year with up to seven days paid leave for marriage, death of close family members, professional examinations and other employer requirements. ${ }^{13}$

Men are still considered to be the heads of the household and are expected only to work. Women are expected to juggle a full-time work schedule by doing the housework, taking care of the children, making meals, etc.

As we point out, our country has a 40-hour working week with a 30 minute rest period during daily working hours plus sick leave benefits. ${ }^{14}$ Following EU standards, flexible employment contracts and flexibility of working time are available in the Republic of North Macedonia. ${ }^{15}$

Harmonization policies for work-life balance are covered by both social and labor legislation. They usually include:

1. Availability of affordable services - Institution for early childhood education and care and residential care centers for adults;

2. Right to unpaid / paid leave;

3. Flexible work engagement - a free and flexible work approach;

4. Cash benefits.

Below we have reviewed each of the policies with suggestions for their possible correction.

\subsection{Affordable services - Institution for early childhood education and care - kindergartens and residential care centers for adults}

Surveys on time-use show that women usually do most of the unpaid housework and childcare, so these family responsibilities can affect women's inclusion in the labor market. The extent and form of women's participation in the labor market are often related to whether they have young children or other persons in their care-seeking households.

\footnotetext{
12 Ibid, article 134

13 Ibid, article 137 and 146

14 Ibid, article 131 and 112

15 Ibid, article $46-54$
} 
Data show that gender gaps in employment in North Macedonia - 19 percentage points, are driven mainly by the very low labor force participation of women. ${ }^{16}$ Employment rates for women are lower than men at all levels of education, although the differences decline somewhat at higher education levels. Few women in North Macedonia work part-time, though the main reason for part-time work is the lack of full-time jobs, followed by "other family or personal responsibilities" and "looking after children and incapacitated adults." Mothers, particularly those with small children up to the age of 6 , are much less likely to be employed relative to non-mothers. The main overall impediments to female work activities, as reported by women themselves in the Labor Force Survey, are "family/caring responsibilities" and "other personal and family obligations." 17 Studies show that the traditional division of household labor in which the burden of care for the household and its dependents automatically falls on women represents a substantial impediment to women's work activities in the labor market in North Macedonia. In other words, the high competing demand for women's time to care for the household and its dependent family members (children and the elderly) leads to low female attachment to the labor market. Study shows that a higher number of respondents from North Macedonia relative to the EU countries believes that "it is better for everyone involved that the man earns the money and the woman takes care of the home and children." 18 The share of people who agree with this statement is highest among the self-employed and the jobless. One-third of women in North Macedonia believe that their primary role is to give birth and take care of the home and family rather than to work, 38 percent believe that it is more difficult for women to be managers and politicians or in top positions, and 40 percent believe that working mothers cannot establish as close a relationship with their children as non-working mothers. Inactive women are more likely to hold each of these strongly traditional views. ${ }^{19}$

An insufficient supply of childcare services puts further constraints on female work activities. Several issues related to eldercare (the inadequate availability of services, the amount of time involved, the social norms that limit the use of residential care) are also seen as obstacles to female work activities. On the other hand, increasing the number of children in the family has little effect on the employment rate of male parents.

16 Based on the Labor Force Survey, [https://countryeconomy.com/labour-force-survey/macedonia], accessed 10. February 2020

17 Dávalos, M, E., Trends in Labor Markets in FYR Macedonia: A Gender Lens, World Bank, 2018, p. 3

18 Mojsoska, B., N.; Petreski, M.; Öztas, A., "National Research on Low Female Labour Market Participation (Quantitative Based Evidence from a New Survey)." Skopje, UN Women, 2017, p. 27

19 Ibid. 
As childcare is often an obstacle for women working full time, providing childcare services is very important. Childcare facilities mostly serve children of mothers who are working full-time or part-time. One of the main reasons for the initiative to extend maternity leave in the Republic of North Macedonia was the inadequate conditions in kindergartens. Quality is important for potential users of formal care services for children and the elderly. So, even in a situation where maternal leave would increase, the problem of inaccessibility and quality of services in kindergartens remains unresolved, i.e. after the expiry of parental leave, parents will face the same problem again - lack of adequate quality of kindergarten services where they will have to leave their children. Therefore, it is necessary to have quality conditions in kindergartens throughout the country. Supply of eldercare with day-based services and availability of inexpensive residential care centers. This is one of the key measures that will positively impact the balance between work and family life and increase women's participation in the labor market.

\subsection{Right on unpaid / paid leave}

First, a clear distinction should be made between maternity leave, parental leave and paternity leave. In the Member States, division of the leave is made by determining the obligation and length of use by parents. The exercise of these rights plays a key role in the employment rate of women. The effectiveness of leave policies depends on several factors, such as the level of payment, length of leave, flexibility to use leave and the employment sector (public or private).

Another aspect that is often missing in leave policies is equal opportunities for women and men. If it is mainly women who are taking long parental leave, then this can reinforce stereotypical assumptions about the domestic responsibilities of men and women and may encourage discrimination. The fact that father leave is usually not taken into account in policies to reconcile work and family life can result in problems of reintegrating women back into the labor market, as well as reinforcing gender segregation as few fathers make use of such absence, although it is in principle available to them as well.

The North Macedonia legislation does not specifically regulate or protect the right to paternity leave, and no incentives exist to encourage men to take leave for childcare. Implicitly, the legislation protects the right of fathers to take a very short paid leave due to fatherhood (2-7 days, which is currently being further regulated through collective (bargaining) agreements). In 2014, the authorities introduced an unpaid paternity leave of up to three months until the child reaches the age of 3 . However, although it was intended to serve as potential leave to be used by any parent, the Labor Code delegates this right to "female workers," whereas the Law on Mandatory 
Social Contributions uses the general term "worker." Although the right to maternity leave can be used by either of the parents, there is a negligible take-up rate of parental leave by fathers. Data from the Health Insurance Fund show that in 2017, there were in total only 79 fathers who used this benefit instead of the mothers (about 0.76 percent of the total number of people who took parental leave).

Gender inequality in the absence of paternity leave can be remedied through several institutional measures, such as:

- Adoption of policies for longer compulsory paid leave for the father. For example, at least 40 days until the mother recovers from childbirth. The Law on Labor Relations of the Republic of Northern Macedonia offers an opportunity, but not as an exclusive right to paid paternity leave. Fathers can take leave only if the mother does not exercise the right to maternal leave. ${ }^{20}$ The right for its use is left to the father's choice because it is not compulsory. This can be an issue because in the society we live in, it carries with it a great deal of prejudice.

- Using parental leave based on the part-time model.

- Flexible paid leave policies. The current Law on Labor Relations provides only continuous maternity leave. ${ }^{21}$

- Supporting breastfeeding in the workplace by providing appropriate breaks and/ or privacy breaks. Past research suggests that breastfeeding provisions might be more efficient in increasing breastfeeding rates when; they are combined with another set of family-friendly policies (such as shared parental leave); the organizational culture is supportive (where support by the line manager is crucial); and support is provided from a combined set of environments concurrently (such as work, home, community, health system). Past research also seems to indicate that interventions in the workplace to support breastfeeding might benefit mothers with lower socioeconomic status most. ${ }^{22}$

- Right to postpone use of leave.

\subsection{Flexible work engagement - a free and flexible work approach}

The literature lacks the evidence of flexible working hours impacting the work-life balance. However, two concepts are frequently used together in the studies. Flexible working hours have been introduced as a benefit for parent/caring employ-

20 Law on Labour Relations (Official Gazette No. 62/2005) and its amendments (Last change Official Gazette No. 27/2016), article 167

$21 \quad$ Ibid, article 165

22 Vaganay, A.; Canónico, E.; Courtin, E., Challenges of work-life balance faced by working families, Directorate-General for Employment, Social Affairs, and Inclusion, European Commission, Brussels, 2016, p. 17 
ees to help them fulfilling work and life responsibilities and achieving work-life balance. In the recent work-life balance survey, researchers found that employees believe that flexible working practices improves workplace morale, which might positively influence work-life balance. Also, employees believe that employers can help them balance their work and life roles. As an example, flexible working hours is one of the best activities to increase employee wellbeing, as it helps an employee deal with responsibilities outside the workplace. ${ }^{23}$

Employment law emerged and evolved along with economic changes. Flexible working hours have recently gained a lot of attention from organizations and scholars as family-friendly policies. Nowadays, flexible working hours are becoming important to workplaces. A lot of organizations offer flexible working hours to employees due to the benefits that flexibility gives to both employee and employer. Greater employee productivity and higher organization profitability are the most common benefits. ${ }^{24}$

Also, flexible working hours promote and facilitate work-life balance. Reduced stress and increased employee wellbeing are outcomes of the work-life balance. Besides, some researchers argue that flexible working practices facilitate work-life balance, and with shifting family patterns such practices are beneficial for both women and men. ${ }^{25}$

The existence and development of different forms of work have been repeatedly acknowledged by the European institutions. In its Green Paper on modernizing labor law of November 2006, the European Commission noted that: „Rapid technological progress, as well as globalization, have fundamentally changed European labor markets. Fixed-term contracts, part-time work, on-call and zero-hours contracts, hiring through temporary employment agencies and freelance contracts have become an established feature of the European labor market, accounting for 25\% of the workforce". ${ }^{26}$ As the Lisbon strategy illustrates, Europe's achievement of the labor market targets fixed in 2000 and revised in 2005 relied on developing forms of "atypical or non-standard" work arrangements that allow "for more flexibility, either internal or external quantitative flexibility. Non-standard forms of employment

23 Pruyne, E.; Powell, M.; Parsons, J., Developing a Strategy for Employee Wellbeing: A Framework for Planning and Action," Ashridge Business School, Nuf-field Health, 2012

24 Shagvaliyeva, S., Impact of Flexible Working Hours on Work-Life Balance, American Journal of Industrial and Business Management, vol. 4, no. 1, 2014, p. 20-23

25 Thomson, P., The Business Benefits of Flexible Working, Strategic HR Review, vol. 7, no. 2, 2008, pp. 17-22, [http://dx.doi.org/10.1108/14754390810853129], accessed 05. June 2020

26 European Commission, 2006 
allow for adapting hours of work, organization of working time and the responsiveness of work to fluctuations in the demand for production or services" ${ }^{27}$

On the other hand, as these forms of work have only developed in more recent times, some adjustments to the rights and protection of workers are needed to adapt to these "new" situations. The majority of workers' rights and protection have been built around so-called "standard" employment relationships - the main features being the permanence of a contractual relationship between the worker and an employer, with rights and protection being developed along the way. Some of the principal characteristics of work such as pay increases, participation in the representative process, unemployment subsidies and pension rights are linked to employment tenure. Moreover, new flexible payment schemes and vocational training systems also appear to be linked to job tenure. The so-called "standard" employment arrangements are considered as ensuring employment tenure and therefore guaranteeing the whole range of rights and protection linked to this form of employment. ${ }^{28}$

The choice between working in a job and caring for a family member also depends on the structure of the labor market. When the labor market is open to the development of part-time and flexible working hours, reconciling a job and caring at home is feasible, especially for women (with the extreme and exceptional example of the Netherlands, where the female part-time rate represents more than half of female employment). In contrast, in countries where this opportunity is rare or difficult, such as in Greece, Croatia (culture), in Lithuania (employer attitudes), Romania or Serbia, experts consider that the structure itself pushes female workers out of the labor market. ${ }^{29}$

The traditional eight-hour working day is no longer the norm in North Macedonia society, too. The introduction of flexible working hours, part-time work and work from home are not new in our labor law. In 2005, new legislation reforming the North Macedonia labor market came into effect. ${ }^{30}$ The law introduces numerous innovations in terms of employment services and contracts - such as part-time work, on-call work, project work and work/training contracts. It also introduced changes regarding the involvement of the social partners in the management of

27 The so-called 'Wilthagen matrix' - Wilthagen, T.; Tros, F., The concept of 'flexicurity': a new approach to regulating employment and labour markets, 2004, p. 171

28 Broughton, A.; Biletta, I.; \& Kullander, M., Flexible forms of work: 'very atypical' contractual arrangements, 2010, p. 3

29 Bouget, D.; Spasova, S.; Vanhercke, B., Work-life balance measures for persons of working age with dependent relatives in Europe, A study of national policies, European Commission, 2016, p. 32

30 Law on Labour Relations (Official Gazette No. 62/2005) 
the labor market. The main aim of the law was to make the North Macedonia labor market more flexible to encourage job creation. The need for flexible employment arrangements has been underlined on several occasions. Developing these forms of work is considered necessary for achieving economic growth through the adaptation of business strategies and productivity to globalized markets and economies. It should be noted that work flexibility offers convenience in planning, not reducing the working time. ${ }^{31}$

Aside from the existing norms of flexible working in the Law on Labor Relations (article 46-53), following possibilities are included:

- Short-time work - a temporary reduction in working time intended to maintain an existing employer/employee relationship. It can involve a partial reduction in the normal working week for a limited period.

- Job sharing or work sharing - is an employment arrangement where typically two people are retained on a part-time or reduced-time basis to perform a job normally fulfilled by one person working full-time. Job share employees, who don't have a constant workload and do not need to constantly commute to a job daily, lower their stress levels, resulting in healthier lives and work-life balances. This type of arrangement allows the employee to work part-time to spend more time with their families, attend school, or pursue other personal interests. New mothers find that it is a way to continue their careers while not having to deal with the stress and guilt that comes with putting their child in full-time daycare.

Flexibility in working hours - refers to the schedule which allows employees to start and finish their workday when they want. This means that employees can come to work earlier or later than the set time. It includes the opportunity to work on Saturdays to meet a maximum of 40 working hours a week.

- Work from home over the phone or video call - accordingly, workers can balance work and housework and reduce travel-related difficulties (costs, travel time, and downtime). People who work from home have an easier time eating healthy and striking a manageable work-life balance. Eating healthier and having more time to spend with your family can help you feel less stressed, which will make for a happier more productive workday.

- Periodic work - potentially very useful for parents who cannot find adequate care during school hours.

- Total annual working hours - such work assignments determine the total number of hours employees are expected to work with normal pay within a period of one year.

31 Atkinson, C.; \& Hall, L., Flexible working and happiness in the NHS, Employee Relations, vol. 33, no. 2, 2011, pp. 88-105 
This kind of work engagement of parents with children up to a certain age can be encouraged by a mild subsidy to employers.

Because of the potential obstacles or challenges that human resource practitioners usually face when they implement work-life balance policies, employers should consider flexitime carefully. How organizations implement work-life balance policies determines their success. ${ }^{32}$

\subsection{Cash benefits}

Cash benefits are another dimension of reconciliation policies. These include family benefits and one-off payment benefits in case of childbirth. In North Macedonia, the recent amendments to the Law on Child Protection introduced a progressive increase in the allowance for newborns. One-off payment benefits for the first child in the amount of 5.000 denars, for the second 20.000 denars and the third newborn 60.000 denars. At the same time, in addition to receiving a one-time allowance, all families with minimum incomes and welfare beneficiaries are given access to the right to child benefits and education benefits. ${ }^{33}$ These amendments intend to reduce child poverty, but not to provide work-life balance.

The objective of striking a good work-life balance for people who have to care for dependent relatives cannot be reached by specific carer's benefits alone. The success of this objective indeed largely depends on the interplay between a broader set of social and employment policies. This balance very much depends on the pattern of family values in society and the gender distribution of economic activity, more precisely on employment and social policies in place allowing people with dependent relatives to balance work and care. ${ }^{34}$

Women under pressure to care for a dependent family member will compare their wages on the labor market to the carer's allowance, and more generally to family income resources. When the cash benefit is low, some experts conclude that it is too low to have a substantial effect on the choice of a relative to move from their job to care for a dependent family member. However, others point to the specific segment of the labor market with unskilled workers, low pay and undeclared work. In this case even a low allowance may have a disincentive effect. ${ }^{35}$

\footnotetext{
32 Mageni, G. F; Slabbert, A.D., Meeting the challenge of the work-life balance in the South African workplace, South African Journal of Economic and Management Sciences, vol. 8, no. 4, 2014, p. 175-186

33 Zakon za zastita na decata, Sl. Vesnik na RM, бp. 170 од 29.12.2010

34 Bouget; Spasova; Vanhercke, op, cit, note 29, p. 11

$35 \quad$ Ibid, p. 32
} 


\section{THE EFFECT OF COLLECTIVE AGREEMENTS}

Governmental initiatives and national or sectoral collective agreements are important for providing the overall framework for a work-life balance strategy. Collective bargaining has been crucial in developing initiatives on flexible working time in EU Member States countries, both at sectoral and at a company level. This is typically done through human resource management policies, often in consultation with workers and/or via collective agreements at a company level. This framework needs to provide sufficient space for developing specific arrangements that serve the needs and preferences of both workers and employers.

Furthermore, within the frameworks provided by these company policies, sometimes the modalities for work-life balance arrangements are formalized in a written agreement between the employer and the worker. Such arrangements can also be included in national, sectoral and/or enterprise-level collective agreements.

For example, in Finland, most collective agreements at local level include the opportunity of developing flexible working time arrangements to help improve work-life balance, but there are large differences between sectors in the way these measures are implemented. One example is the collective agreement for the private social services sector, where the social partners published a guide for companies on the benefits of flexible working time. In Denmark, social partners in the manufacturing sector have tried to encourage the adoption of flexible forms of working at local level. The health of employees in public hospitals in Helsinki and their work-life balance improved when they were given more time between working shifts (a more employer-friendly form of flexible working). In Italy, the recently approved Jobs Act and the draft laws in relation to work-life balance are intended to support flexible working time schemes and promote part-time work to meet parents' needs, including the opportunity to request parental leave on an hourly basis. Companies are offered relief on social security contributions if they address work-life balance through collective bargaining. In Austria, while the statutory working time remains the same, the social partners introduced some new aspects through collective bargaining, including the free time option which allows workers in certain sectors to choose between a wage increase and working time reduction. As a result, workers can reduce working hours to better reconcile work and family responsibilities without losing their existing income. ${ }^{36}$

36 Lave, O. V.; Boehmer, S., Policies to improve work-life balance, Eurofound, Wyattville Road, Ireland, 2015, p. 4 
In our country, however, the topic is a low priority for social partners. There should be efforts to implement existing flexible arrangements at the company-level through social dialogue, supported by central social partners' agreements.

Last but not least, government measures and legislation can also shape the conditions for work-life balance, as well as regulate certain responsibilities in the context of occupational health and well-being.

\section{CONCLUSION}

Extensive policy in all EU Member States suggests that a whole spectrum of measurable benefits or value-adding practices can be seen in a work-life balanced system. Understanding how working time is organized and how this is impacting on the balance of work versus private life is of fundamental importance. A satisfactory work-life balance is achieved when an individual's right to a fulfilled life inside and outside paid work is accepted and respected as the norm, to the mutual benefit of the individual, business and society. The policy has focused on how to increase employment rates among women and older workers, and work-life balance is an important factor in determining their participation.

Harmonization policies for work-life balance are covered by both social and labor legislation. They usually include the availability of affordable services - an institution for early childhood education and care and residential care centers for adults, right on unpaid / paid leave, flexible work engagement - a free and flexible work approach and cash benefits. We have reviewed each of the policies with suggestions for their possible correction.

The issue of how to enable more people to participate in the labor market and to continue to do so until an older age has become a key policy issue in all EU Member States and the Republic of North Macedonia. These challenges might be met by adopting an approach to work that puts sustainability at its center. Sustainable work means that „living and working conditions are such that they support people in engaging and remaining in work throughout an extended working life“.

There is a wide variation on the entitlement of paternity and family leave, with the Member States having much more generous payment or length than our country.

Flexible working practices are beneficial for both employee and employer. Hence, in the first place flexibility was introduced to the workplace to help employees with kids or employees who care for siblings to manage their time between work and life. As flexibility gives an employee the ability to control when, where, and how much time do they work, flexibility contributes to improvement in the allo- 
cation of work and life responsibilities. Thus, an employee might end up fulfilling his/her working as well as well non-working roles easily. Finally, the achievement of inside the work and outside the work responsibilities leads to finding a worklife balance which increases overall life satisfaction. To summarize, it might be said that the use of flexible working practices positively influences on work-life balance and overall life satisfaction of the employee.

While a European legislative framework and the national legislation provide basic rights for parents to reconcile professional and private life, collective agreements have been and will be important in providing much-needed additional rights tailored to specific constituencies. Moreover, collective agreements are important in ensuring the proper implementation of existing rights.

A work-life balance system after the EU Directive on work-life balance for parents and carers, in its purest form, must be applied in the Republic of North Macedonia's workplace due to EU integration. Therefore, further efforts need to be done on a national level. The policy suggestions given in this paper may improve work-life balance during everyday life. However, this still needs to be explored through focused research. The major challenge in the implementation of a worklife balance system in the Republic of North Macedonia will be on the management, which has to learn to manage worker outputs rather than the workers. The country should do its utmost to raise awareness of the directive and encourage the competent institutions to set high standards especially in the area of childhood education and care centers, and residential care centers for adults.

\section{REFERENCES}

\section{BOOKS AND ARTICLES}

1. Atkinson, C.; Hall, L., Flexible working and happiness in the NHS, Employee Relations, vol. 33, no. 2, 2011, pp. 88-105

2. Bouget, D.; Spasova, S.; Vanhercke, B., Work-life balance measures for persons of working age with dependent relatives in Europe, A study of national policies, European Commission, 2016

3. Broughton, A.; Biletta, I.; Kullander, M., Flexible forms of work: 'very atypical' contractual arrangements, 2010

4. Cruz, A., Good practices and challenges on the Maternity Protection Convention, 2000 (No. 183) and the Workers with Family Responsibilities Convention, 1981 (No. 156): A comparative study, International Labor Organization, 2012

5. Dávalos, M, E., Trends in Labor Markets in FYR Macedonia: A Gender Lens, World Bank, 2018,

6. European Commission, A new start to support work-life balance for parents and carers, 2019

7. Greenblatt, E., Work/life balance: Wisdom or whining, Organizational Dynamics, 2002 
8. Kotowska, E.I. et al., Second European Quality of Life Survey: Family life and work, Office for Official Publications of the European Communities, Luxembourg, 2010, pp.1-96.

9. Lave, O, V.; Boehmer, S., Policies to improve work-life balance, Eurofound, Wyattville Road, Ireland, 2015

10. Mageni, G. F; Slabbert, A.D., Meeting the challenge of the work-life balance in the South African workplace, South African Journal of Economic and Management Sciences, vol. 8, no. 4, 2014, p. $175-186$

11. Mojsoska, B, N.; Petreski, M.; Öztas, A., "National Research on Low Female Labor Market Participation (Quantitative Based Evidence from a New Survey)." Skopje, UN Women, 2017

12. Pruyne, E.; Powell, M.; Parsons, J., Developing a Strategy for Employee Wellbeing: A Framework for Planning and Action," Ashridge Business School, Nuf-field Health, 2012

13. Reiter, N., Work Life Balance: What DO You Mean? The Ethical Ideology Underpinning Appropriate Application, The Journal of Applied Behavioral Science, NTL Institute, 2007

14. Shagvaliyeva, S., Impact of Flexible Working Hours on Work-Life Balance, American Journal of Industrial and Business Management, vol. 4, no. 1, 2014, p. 20-23

15. Vaganay, A.; Canónico, E.; Courtin, E., Challenges of work-life balance faced by working families, Directorate-General for Employment, Social Affairs, and Inclusion, European Commission, Brussels, 2016

16. Wilthagen, T.; Tros, F., The concept of 'flexicurity': a new approach to regulating employment and labor markets, 2004

\section{INTERNATIONAL LABOR CONVENTIONS AND RECOMMENDATION}

1. Convention Maternity Protection Convention, 2000 (No. 183)

2. Part-Time Work Convention, 1994 (No. 175)

3. Part-Time Work Recommendation, 1994 (R182)

4. Reduction of Hours of Work Recommendation, 1962 (R116)

5. Workers with Family Responsibilities Convention, 1981 (No. 156)

6. Workers with Family Responsibilities Recommendation, 1981 (R165)

\section{EU LAW}

1. Directive (EU) $2019 / 1158$ of the European Parliament and of the Council of 20 June 2019 on work-life balance for parents and carers and repealing Council Directive 2010/18/EU

2. European Pillar of Social Rights, Booklet, adopted by The European Parliament, the Council and the Commission, 2017.

\section{LIST OF NATIONAL REGULATIONS, ACTS AND COURT DECISIONS}

1. Law on Labour Relations ("Official Gazette of the Republic of Macedonia" no. 62/05, 106/08, 161/08, 114/09,130/09, 50/10, 52/10, 124/10, 47/11, 11/12, 39/12, 13/13, $25 / 13,170 / 13,187 / 13,113 / 14,20 / 15,33 / 15,72 / 15,129 / 15$ and 27/16)

2. Zakon za zastita na decata, Sl. Vesnik na RM, бр. 170 од 29.12.2010 


\section{WEBSITE REFERENCES}

1. [https://countryeconomy.com/labour-force-survey/Macedonia], accessed 10. February 2020

2. [https://ec.europa.eu/social/main.jsp?catId=1311\&langId=en], accessed 20. January 2020

3. [https://ec.europa.eu/social/main.jsp?langId=en\&catId=1311\&furtherNews=yes\&newsId=9285], accessed 15. January 2020

4. Thomson, P., The Business Benefits of Flexible Working, Strategic HR Review, vol. 7, no. 2, 2008, pp. 17-22, [http://dx.doi.org/10.1108/14754390810853129], accessed 05. June 2020 